\title{
Effects of feed supplementation period on some reproductive parameters of female cane rats (Tryonomys swinderianus)
}

\author{
F. Ngoula*, F. Ajiahoung Kemassong, H. Defang Fualefac, A. Kenfack, A. Téguia and \\ J. Tchoumboué \\ Department of Animal Sciences, Faculty of Agronomy and Agricultural Sciences, University of Dschang, \\ Dschang-Cameroon.
}

Accepted 16 November, 2012

\begin{abstract}
Cane rat is a wild histricomorph rodent hunted in Africa for its meat. Domestication attempts have not been as successful as desired due to paucity of informations on its reproduction and fertility. In the present study, we investigated the effects of feed supplementation period on some reproductive parameters of cane rats. For this purpose, two experimental diets: Control diet $(40 \%$ wheat brand and $60 \%$ maize) commonly used by cane rat farmers and complete diet $(13 \%$ maize flour, $18 \%$ wheat bran, $16 \%$ cassava flour, $30.25 \%$ palm kernel meal, $5 \%$ soya bean cake, $13 \%$ cotton cake, $3 \%$ palm oil and $1.75 \%$ oyster shell) prepared in the laboratory, were randomly distributed into four groups of six cane rats each. Four treatments were considered: T0, control diet; T1, complete diet; T2, T0 diet until the positive pregnancy test and then supplemented with T1 diet, and T3, T0 diet up to 50 days after the positive pregnancy test and then supplemented with T1 diet. Primiparous female cane rats that received treatments $\mathrm{T} 1$ and $\mathrm{T} 2$ registered the highest fertility rate $(100 \%)$. For multiparous, fertility rate was significantly higher $(p<0.05)$ with T3 $(83.3 \%)$ compared to T2. Generally, litter size in primiparous rats was significantly higher in treatment $\mathrm{T} 1$ compared to other treatments. The mortality rate of females at birth was significantly $(p<0.05)$ higher in primiparous $41.1 \pm 16.4 \%$ compared to multiparous $(8.3 \pm 14.4 \%)$. The pre-weaning mortality was significantly $(p<0.05)$ higher in multiparous pups compared to primiparous ones during the same period. It could be concluded that supplementing the diet of cane rat increased fertility rate and litter size in primiparous females.
\end{abstract}

Key words: Feed supplementation period, pregnancy, fertility, prolificacy, mortality, cane rat.

\section{INTRODUCTION}

African wild fauna is one of the most important of all the continents. It constitutes for the human population, a considerable food resource (FAO, 1990). The consumption of bush meat is deeply anchored in the food habits of African populations. Thus, a strong pressure exerted by man on the fauna to satisfy the bush meat demand has a direct incidence on the fauna population

${ }^{*}$ Corresponding author. E-mail: fngoula@yahoo.fr. Tel: +237 97941676. and constitute a serious threat on the survival of the biodiversity (Ajayi, 1997; Patrick et al., 2004).

Hardouin (1981), after an analysis of the famine state in the world and particularly, the problem of animal protein deficiency in developing countries, presented the breeding of non conventional species as one of the alternatives for genetic diversification and fight against poaching. Among the wild animals domesticated in Africa, one can quote the Gambia rat (Crycetomis gambianus), frog (Rana esculenta), giant snail (Achachatina marginata) and cane rat (Tryonomys swinderianus). 
The grasscutter (Thryonomys swinderianus), also known as the African great cane rat, is a wild hystricomorph rodent widely distributed in the African sub-region and exploited as a source of animal protein (Asibey, 1974; Vos, 1978; N.R.C., 1991). Grasscutter is known for its excellent taste, higher nutritional values (Asibey and Addo, 2000; Omole et al., 2005). It is perhaps the most expensive of the preferred meats in West Africa (N.R.C., 1991) and is therefore hunted aggressively. Thus, the excessive and uncontrolled decimation of this animal for consumption pose a threat to the ultimate survival of the species (Opara, 2010). Consequently, there is need to encourage domestication of grasscutter by making breeding and fattening stock readily available for intending producers or farmers. This can be achieved because like rabbits, grasscutters are reflex ovulators and could therefore ovulate as a result of an orgasm induced by contact with other females (Fayenuwo et al., 2003). Hemmer (1992) also points out that this animal is able to reproduce all year round.

While the beneficial effects of nutrition on the fertility of cane rat had been studied (Lameed and Ogundijo, 2006; Taiwo et al., 2009), the effect of feed supplementation during pregnancy on fertility remains unknown. Thus, a good understanding of the nutritive requirement at different pregnancy stages is very vital.

The present work was therefore undertaken in order to evaluate the effects of feed supplementation period on some reproductive parameters of cane rats under captivity.

\section{MATERIALS AND METHODS}

\section{Experimental location}

The study was carried out at the Teaching and Research Farm of the Department of Animal Science, University of Dschang (LN 5 to $7^{\circ}$, LE 8 to $\left.12^{\circ}\right)$. Dschang is located in the Western Sudanoguinean savanna of Cameroon at an altitude of $1500 \mathrm{~m}$ above sea level. Wind speed is $1.60 \mathrm{~m} / \mathrm{s}$; mean temperature is $20^{\circ} \mathrm{C}$ and relative humidity generally exceeds $60 \%$. Annual rainfall varies between 1910 and $2010 \mathrm{~mm}$. The raining seasons goes from midMarch to mid-November and the dry season from mid-November to mid-March.

\section{Experimental animals}

The breeding stock consisted of six males, weighing 2500 to $3000 \mathrm{~g}$ and 26 females (11 primiparous and 15 multiparous) weighing between 2500 and $3000 \mathrm{~g}$. At the beginning of the trial, all the females were dewormed with levacipß $(1 \mathrm{~g} / \mathrm{l}$ of water). Lemon juice and sugar were added to drinking water periodically (once per week) as anti-stress.

\section{Experimental diets}

In addition to basal diet made up of Pennisetum purpureum, two different supplements were prepared: The control (usually used by cane rats farmers) and complete diets. The composition and chemical characteristics of experimental diets are presented in Table 1. The complete feed was made in the form of a ball of $40 \mathrm{~g}$ on average after a mixture with boiling water at a rate of $800 \mathrm{ml} / \mathrm{kg}$ and dried at $50^{\circ} \mathrm{C}$ in an oven for $48 \mathrm{~h}$.

\section{Experimental design}

The female cane rats were put into groups of similar body weights and were randomly allocated to four treatment groups, with one vigorous male per group. The four treatment groups considered in the study were: T0, control diet all through the study; T1, complete diet all through the study; T2, T0 diet until the positive pregnancy test and then supplemented with T1 diet, and T3, T0 diet up to 50 days after the positive pregnancy test and then supplemented with T1 diet. The experimental design was randomized complete block. Feed and water for the animals were given ad libitum.

The female cane rats were weighed at the beginning of the test and at delivery. Their offsprings were also measured.

\section{Data collection}

Data on the following variables were collected from female cane rats and their offspring: Feed consumption; Live body weight before mating and delivery, and weaning; Fertility rate $(\%)=($ Number of positive mating/Number of females introduced to a male) $\times 100$; Gestation length (days) = Date of delivery - Date of positive pregnancy test +40 days; Litter size $=$ Number of pups at birth; Prolificacy rate $(\%)=($ Number of pups born / Number of delivery $) \times$ 100; $\mathrm{Se}^{\mathrm{x}}$-ratio $(\mathrm{M} / \mathrm{F})$ at birth $=$ (Number of males born alive $/$ Number of females born alive) $\times 100$; Mortality rate at birth $(\%)=$ (Number of still birth / Number of pups born alive) $\times 100$; Mortality rate before weaning $(\%)=$ (Number of pups deaths before weaning/ Number of pups weaned) $\times 100$; Mortality rate after weaning $(\%)=$ Number of pup's death between 21 and 56 days/Number of pups born alive $\times 100$.

\section{Statistical analysis}

Data collected were tested for normality before subjected to analysis of variance. Analysis of variance (ANOVA) was performed to compare treatment means at probabilities of $5 \%$. When differences in means were declared significant, they were separated using the Duncan Multiple Range test. Due to the analysis of variance which was performed on many variables in the same dataset, Bonferroni correction was performed before statistical significance could be declared. Statistical analyses were performed using SPSS for windows software program (Release 17.0).

\section{RESULTS}

The effect of feed supplementation period on average feed and water consumption, body weight gain, daily weight gain and feed conversion ratio of pregnant cane rat are summarized in Table 2 .

Animals subjected to treatment T3 (receiving complete diet 50 days after the positive pregnancy test) ingested more feed $(P<0.05)$ than those of treatment $T 1$ (receiving diet as from mating). Water consumption remained unchanged when compared to the control irrespective 
Table 1. Composition and chemical characteristics of experimental food.

\begin{tabular}{lcc}
\hline \multirow{2}{*}{ Ingredient } & \multicolumn{2}{c}{ Composition (\%) } \\
\cline { 2 - 3 } Maize flour & Control feed & Test feed \\
wheat bran & \multicolumn{1}{c}{13} \\
Cassava flour & $/$ & 18 \\
Palm kernel meal & $/$ & 16 \\
Soya bean cake & $/$ & 30.25 \\
Cotton cake & $/$ & 5,00 \\
Maize (grains) & 60 & 13 \\
Palm oil & $/$ & $/$ \\
Oyster shell & $/$ & 3.00 \\
Total & 100 & 1.75 \\
& & 100 \\
Bromatologic composition (\% DM) & & \\
dry Matter & 90.01 & \\
Organic matter & 96.70 & 89.84 \\
Crude protein & 11.90 & 92.90 \\
Crude fibre & 6.70 & 19.71 \\
Lipid & 0.88 & 18.56 \\
Ashes & 3.29 & 1.89 \\
Calcium & 0.058 & 7.09 \\
Phosphorus & 0.642 & 1.00 \\
Metabolisable energy (kcal/kg ms) & 3269.46 & 0.60 \\
\hline
\end{tabular}

of treatment $(P>0.05)$. The body and daily weight gains were not significantly $(P>0.05)$ affected by the treatments considered. The lowest feed conversion ratio was recorded with pregnant females of treatment T2 and the highest observed with treatment T1. However, the difference in feed conversion was not significant.

The effects of feed supplementation period on reproductive parameters are summarized in Table 3 . Due to the reduced number of females, treatment T3 was not applied on primiparous females and treatment $\mathrm{T} 1$ on multiparous females. Pregnant females of treatment T2 were heavier than those of other treatments although the differences were not significant.

In general, the fertility rate was higher in primiparous than in multiparous females although the difference was not significant $(P>0.05)$. On the other hand, in primiparous females, the fertility rate at first delivery was significantly higher $(\mathrm{P}<0.05)$ in treatments $\mathrm{T} 2$ and $\mathrm{T} 1$ compared to T0, while in multiparous females, T0 and T3 were significantly higher compared to $\mathrm{T} 2$.

The gestation length for the first and second delivery varied between 151 and 158 days and 151 and 162 days, respectively. No significant differences $(P>0.05)$ were observed between treatments for this parameter. The number of male kids were significantly $(P<0.05)$ higher in multiparous than in primiparous females. The litter size at first delivery ranged from 6 to 13 kids whereas for multiparous females, it varied from 9 to 14 kids.
At first delivery, the prolificacy rate varied from 300 to $320 \%$ whereas at the second delivery it varied from 300 to $350 \%$. In the first delivery, animals fed diet T1 were highly prolific whereas in the second delivery, the most prolific animals were fed diet T3. Nevertheless, no significant difference $(P>0.05)$ was observed between treatment groups. Generally, the proportion of male pups (sex-ratio) was significantly higher in multiparous compared to primiparous females. In addition, in primiparous females, the sex-ratio was significantly $(P<0.05)$ higher for animals fed control diet (T0) compared to other treatments.

Mortality at birth was in general significantly $(P<0.05)$ higher in female kids born from primiparous females as compared to those born from multiparous females irrespective of treatment. Generally, pre-weaning mortality was significantly $(P<0.05)$ higher for multiparous than primiparous females irrespective of treatment.

\section{DISCUSSION}

At the end of the experiment, pregnant females of treatment T2 were heavier than those of other treatments even though the differences were not significant. This result suggests that the distribution of complete feed from the positive pregnancy test would be recommended to improve the nutritional status of the breeders while 
Table 2. Effects of feed supplementation period on food consumption, weight, daily weight gain and feed conversion ratio of pregnant cane rat.

\begin{tabular}{|c|c|c|c|c|c|c|c|}
\hline \multirow{2}{*}{ Treatment } & \multicolumn{2}{|c|}{ Consumption } & \multicolumn{2}{|c|}{ Weight (g) } & \multirow{2}{*}{ Body weight (g) } & \multirow{2}{*}{$\begin{array}{c}\text { Daily weight gain } \\
(\mathbf{g} / \mathbf{J})\end{array}$} & \multirow{2}{*}{ FCR } \\
\hline & Feed (g/DM) & Water (ml) & Initial & Final & & & \\
\hline To & $23861 \pm 3509^{a b}$ & $631.9 \pm 156.4^{\mathrm{a}}$ & $2767 \pm 413^{a}$ & $3750 \pm 288^{a}$ & $983 \pm 194^{a}$ & $8.78 \pm 1.73^{\mathrm{a}}$ & $25.25 \pm 6.89^{a}$ \\
\hline $\mathrm{T} 1$ & $20387 \pm 1796^{b}$ & $520.0 \pm 158.2^{a}$ & $2460 \pm 619^{a}$ & $3340 \pm 541^{a}$ & $880 \pm 319^{a}$ & $7.85 \pm 2.85^{\mathrm{a}}$ & $27.27 \pm 15.05^{a}$ \\
\hline $\mathrm{T} 2$ & $22885 \pm 4817^{\mathrm{ab}}$ & $544.5 \pm 133.2^{a}$ & $2475 \pm 411^{a}$ & $3650 \pm 520^{a}$ & $1175 \pm 171^{a}$ & $10.49 \pm 1,52^{a}$ & $19.88 \pm 5.97^{\mathrm{a}}$ \\
\hline T3 & $25641 \pm 854^{a}$ & $624.9 \pm 163.9^{a}$ & $2920 \pm 327^{a}$ & $3920 \pm 319^{a}$ & $1000 \pm 100^{a}$ & $8.92 \pm 0.89^{a}$ & $25.80 \pm 2.13^{\mathrm{a}}$ \\
\hline
\end{tabular}

${ }^{a, b}$ Values on the same column, with the same letter do not differ significantly $(P<0.05)$. FCR, Feed conversion ratio.

Table 3. Effect of feed supplementation period and parity on some reproductive characteristics.

\begin{tabular}{|c|c|c|c|c|c|c|c|c|c|}
\hline \multirow{2}{*}{ Parameter } & & \multicolumn{3}{|c|}{ Primipare } & \multirow{2}{*}{ Mean } & \multicolumn{3}{|c|}{ Multipare } & \multirow{2}{*}{ Mean } \\
\hline & & $T_{0}$ & $T_{1}$ & $\mathbf{T}_{2}$ & & $\mathbf{T}_{0}$ & $T_{2}$ & $\mathbf{T}_{3}$ & \\
\hline \multicolumn{2}{|l|}{ Fertility rate (\%) } & $66.6 \pm 0.0^{a}$ & $100 \pm 0.0^{c}$ & $100 \pm 0.0^{c}$ & $88.8 \pm 19.2^{a}$ & $80.0 \pm 0.0^{b}$ & $66.6 \pm 0.0^{a}$ & $83.3 \pm 0.0^{b}$ & $76.6 \pm 8.8^{a}$ \\
\hline \multicolumn{2}{|l|}{ Duration of gestation days) } & $158.5 \pm 0.5^{\mathrm{a}}$ & $158.5 \pm 0.8^{\mathrm{a}}$ & $151.5 \pm 4.5^{\mathrm{a}}$ & $156.1 \pm 4.0^{\mathrm{a}}$ & $151.5 \pm 9.2^{a}$ & $162.6 \pm 4.7^{\mathrm{a}}$ & $154.6 \pm 2.9^{a}$ & $156.2 \pm 5.7^{\mathrm{a}}$ \\
\hline \multirow{2}{*}{ Litter size } & $\hat{0}$ & $3.0 \pm 0.0^{\mathrm{a}}$ & $3.0 \pm 0.7^{\mathrm{a}}$ & $1.0 \pm 0.0^{\mathrm{a}}$ & $2.3 \pm 1.1^{\mathrm{a}}$ & $6.0 \pm 1.0^{\mathrm{b}}$ & $5.0 \pm 0.5^{\mathrm{ab}}$ & $7.0 \pm 0.9^{b}$ & $6.0 \pm 1.0^{b}$ \\
\hline & q & $3.0 \pm 0.0^{\mathrm{a}}$ & $10.0 \pm 1.0^{\mathrm{b}}$ & $5.0 \pm 0.7^{a}$ & $6.0 \pm 3.6^{\mathrm{a}}$ & $4.0 \pm 1.4^{\mathrm{a}}$ & $4.0 \pm 0.5^{\mathrm{a}}$ & $7.0 \pm 0.5^{\mathrm{ab}}$ & $5.0 \pm 1.7^{\mathrm{a}}$ \\
\hline \multicolumn{2}{|l|}{ Prolificacy rate (\%) } & $300.0 \pm 0.0^{\mathrm{a}}$ & $325 \pm 123.7^{a}$ & $300 \pm 141.4^{a}$ & $308.3 \pm 14.4^{a}$ & $333.3 \pm 47.1^{\mathrm{a}}$ & $300.0 \pm 23.5^{\mathrm{a}}$ & $350.0 \pm 0.0^{\mathrm{a}}$ & $327.7 \pm 25.4^{\mathrm{a}}$ \\
\hline \multicolumn{2}{|l|}{ Sex-ratio (M/F) } & $1 / 1^{b}$ & $1 / 3^{a}$ & $1 / 5^{\mathrm{a}}$ & $1 / 2^{a}$ & $3 / 2^{b}$ & $1 / 1^{a}$ & $1 / 1^{a}$ & $1.1 / 1^{b}$ \\
\hline \multirow{2}{*}{ Mortalities at birth } & $\hat{0}$ & $0.0^{\mathrm{a}}$ & $0.0^{\mathrm{a}}$ & $0.0^{\mathrm{a}}$ & $0.0^{\mathrm{a}}$ & $0.0^{\mathrm{a}}$ & $0.0^{\mathrm{a}}$ & $14.2^{b}$ & $4.7 \pm 8.1^{\mathrm{b}}$ \\
\hline & q & $33.3^{\mathrm{a}}$ & $30.0^{\mathrm{a}}$ & $60.0^{\mathrm{b}}$ & $41.1 \pm 16.4^{\mathrm{a}}$ & $0.0^{\mathrm{a}}$ & $25.0^{b}$ & $0.0^{\mathrm{a}}$ & $8.3 \pm 14.4^{b}$ \\
\hline \multirow{2}{*}{ Pre-weaning mortalities } & $\pi$ & $0.0^{\mathrm{a}}$ & $0.0^{\mathrm{a}}$ & $0.0^{\mathrm{a}}$ & $0.0^{\mathrm{a}}$ & $0.0^{\mathrm{a}}$ & $0.0^{\mathrm{a}}$ & $14.2^{b}$ & $4.7 \pm 8.1^{b}$ \\
\hline & q & $0.0^{\mathrm{a}}$ & $0.0^{\mathrm{a}}$ & $0.0^{\mathrm{a}}$ & $0.0^{\mathrm{a}}$ & $25.2^{b}$ & $0.0^{\mathrm{a}}$ & $0.0^{\mathrm{a}}$ & $8.4 \pm 14.5^{b}$ \\
\hline \multirow{2}{*}{ post weaning Mortalities } & $\lambda$ & $16.6^{\mathrm{a}}$ & $0.0^{\mathrm{b}}$ & $0.0^{\mathrm{b}}$ & $5.6 \pm 9.5^{\mathrm{a}}$ & $0.0^{\mathrm{a}}$ & $0.0^{\mathrm{a}}$ & $0.0^{\mathrm{a}}$ & $0.0^{\mathrm{b}}$ \\
\hline & o & $0.0^{\mathrm{a}}$ & $0.0^{\mathrm{a}}$ & $0.0^{\mathrm{a}}$ & $0.0^{\mathrm{a}}$ & $0.0^{\mathrm{a}}$ & $0.0^{\mathrm{a}}$ & $0.0^{\mathrm{a}}$ & $0.0^{\mathrm{a}}$ \\
\hline
\end{tabular}

${ }^{a, b}$ Values on the same line with the same letter are comparable $(P>0.05)$.

allowing them to effectively cover their dietary needs during pregnancy.

Water consumption was similar for all treatments and was within the limits reported by other authors. Fantodji and Soro (2004) reported $126 \mathrm{ml}$ in adult cane rat. The fertility rate recorded in the present study is in conformity with that reported by Mensah and Ekue (2003). Although the length of gestation period obtained in our study was four 
days longer that that reported by Houben et al. (2004) and two days shorter than that reported by Ngoula et al. (2009), the difference is not significant and could be due to exogenic factors (particularly geoclimatic) and also to individual variations in the animals, considering the number of cane rats used in the present study.

The litter size was within the limits found by Scharge and Yewadan (1995) and Ngoula et al. (2009) at the first delivery. At the second birth, it was $17 \%$ higher than that recorded by Ngoula et al. (2009) in multiparous females. Litter size is usually influenced by factors such as live birth at puberty and the number of births. The sex ratio $(\mathrm{M} / \mathrm{F})$ at birth was similar to the observations made by Mensah and Ekue (2003) and Ngoula et al. (2009) in multiparous females. It was significantly $(\mathrm{P}<0.05)$ lower in primiparous compared to multiparous females, a situation we could not justify with available literature.

The prolificacy rate obtained in this work is comparable with that reported by Scharge and Yewadan (1995). It is however $41 \%$ lower than that recorded by Nguema and Edderai (2000). This difference could be related to the colony used and the feed quality. The birth weight obtained in this study is higher than that found by Scharge and Yewadan (1995), Nguema and Edderai (2000) and Ngoula et al. (2009). This weight improvement of the young cane rats can be linked to better feeding of the mothers particularly during pregnancy. At birth, the male pups were heavier than females. The body weight evolution followed the same logic and translated the sexual dimorphism of weight evoked by Mensah and Ekue (2003) and which was in favour of males.

The mortality rates at birth $(6.7 \pm 9.1 \%)$ were comparable with those obtained by Nguema and Edderai (2000) then Ngoula et al. (2009) at the second delivery. They were significantly higher in primiparous than multiparous females. This difference could be attributable to dystochia related to the youthfulness of these females. Pre-weaning mortalities obtained were 12.5 and $28 \%$ higher than those recorded by Nguema and Edderai (2000) and Fantodji and Soro (2004) respectively.

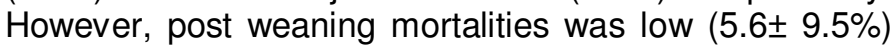
and respectively represented $1 / 3$ and the double of the values reported by these authors. This difference could be attributed to the breed and certain exogenic factors related to the environment where each study was conducted.

It could then be concluded that cane rats subjected to T3 consumed more food than those subjected to other treatments. The period at which females were supplemented with feed did not have any significant effects on daily weight gain and feed conversion ratio (FCR).

Treatment T1 increased fertility rate and favoured delivery of female pups in primiparous than in multiparous females. Treatment T3 did not have any effect on fertility rate, prolificacy rate, pregnancy length, litter size and post weaning mortality. Supplementation of the female cane rats with complete food before crossing or from the positive test of gestation could be recommended to the cane rats breeders.

\section{REFERENCES}

Ajayi S (1997). Ouvrage sur l'aménagement durable des forêts. Etude FAO- Rome. p. 122

Asibey EOA (1974). Wildlife as a source of protein in Africa South of the Sahara. Biol. Conserve. 6:32.

Asibey EOA, Addo (2000). The Grasscutter, a Promising Animal for Meat Production. In: African Perspective Practices and Policies Supporting Sustainable Development, Turnham, D. (Ed.). Weaver Press, Zimbabwe.

Fantodji A, Soro D (2004). L'élevage d'aulacodes. Expérience en Côte d'Ivoire, GRET, Paris. p. 131

FAO (1990). The ADMADE programm, a traditionnal approach to wildlife management in Zambia, part of seminar paper on rural community participation in intergrited wildlife management and utilisition in Botswana, Zambia and Zimbabwe. FO: TCP/RAF/8965, Rome.

Fayenuwo JO, Akande M, Taiwo AA, Adebayo AO, Saka JO (2003). Guidelines for grasscutter rearing technical bulletin. Institute of Agricultural Research and Training, Obafemi Awolowo University, lbadan, Nigeria.

Hardouin J (1981). Possibilités actuelles dans la recherche de sources différentes d'alimentation. Symposium Malnutrition du Tiers-Monde: Ac. Roy. Sc. Outre-Mer, Bruxelles. pp. 65-77.

Hemmer H (1992). Domestication: Concept and consequences. Proc. 1st Annu. Conf. grasscutter Prad. Achievements Prospects 1:189200

Houben P, Edderai D, Nzego C (2004). Elevage de l'aulacode; Manuel de l'éleveur ; EMVT-CIRAD ; Montpellier, France. p. 129.

Lameed GA, Ogundijo 00 (2006). Effect of varied dietary protein levels on the reproductive performance of grasscutter (Thryonomys swinderianus) in captivity. J. Anim. Vet. Adv. 5:361-363.

Mensah GA, Ekue MRM (2003). L'essentiel en aulacodiculture. Réseau rongeurs et environnement, Cotonou. p.160.

National Research Council (N.R.C.) (1991). Microlivestock: Little-Known Small Animals with a Promising Economic Future (Vietmeyer Noel ed). National Academy Press, Washington D.C.

Ngoula F, Meutchieye F, Kenfack A, Defang HF, Manfouo Z, Tchoumboue J (2009). Performances de reproduction des aulacodes en captivité en zone soudano-Guinéenne d'altitude de l'Ouest Cameroun. Archivos de Zootechnia. 58:223:441-449.

Nguema MN, Edderai D (2000). Résultats zootechniques de la station d'aulacodiculture D'Owendo. In : Actes du séminaire international sur l'élévage intensif du gibier à but alimentaire en Afrique, Libreville, 2324 mai 2000. p. 75-77.

Omole AJ, Ayodeji I0, Ashaye OA, Tiamiyu AK (2005). Effect of scalding and flaming methods of processing on physiochemical and organoleptic properties of grasscutter meat. J. Appl. Sci. Res $1: 249-252$

Opara MN (2010). The grasscutter 1: Alivestock oftomorrow. Res. J. For. 4 : 119-135.

Patrick H, David E, Charles N (2004). Elevage de l'aulacode; Manuel de l'éleveur ; EMVT-CIRAD; Montpellier, France. p.129.

Scharge R, Yewadan LT (1995). Abrégé d'aulacodiculture. GTZ in TZVerlag, Rossdorf. p. 103.

Taiwo AA, Fayenuwo JO, Omole AJ, Fajimi AK, Fapohunda JB and Adebowale EA (2009). Supplementary effect of concentrate feed o $n$ the performance of cane rats fed basal diet of elephant grass. Nig. J. Anim. Prod. 36:153-160.

Vos AD (1978). Game as food. A report on its significance in Africa and Latin America. Unasylver. 4:2. 